\title{
Research on the Construction of Higher Vocational Public English Teaching Model Based on Autonomous Learning Theory
}

\author{
Ran Maoyang \\ Chongqing College of Electronic Engineering, Chongqing, 401331 \\ mayaran23@163.com
}

Keywords: Higher vocational public English; independent study; teaching mode

\begin{abstract}
The author constructed a teaching mode that is suitable for public English course for higher vocational colleges under the independent study theory by combining with the independent study theory and constructivism. This teaching mode emphasizes on the operational flow of independent study teaching mode, which changes the teacher-oriented "cramming education" and textbook-oriented "bookworm" teaching mode. This changes higher vocational college students' attitude towards English study to some extent, so that English performance of higher vocational college students can be significantly improved. The English teaching mode under the independent study theory has a strong practicability, improves the teaching quality, meets individualized demands of the higher vocational college students, and serving as a reference in the public English classroom teaching in higher vocational colleges.
\end{abstract}

\section{Introduction}

With the gradual acceleration of socialist modernization, independent study has been a hotspot issue in the current educational research field. Various countries around the world regard cultivation of college students' independent study ability as the important educational target of the modernization education. With the transformation of the teaching philosophy under the market economic development, independent study has already become the primary leading thought of the modern teaching reform. Under the guide of the independent study education philosophy, the traditional teaching mode can't complete the teaching target under the new teaching philosophy. The imperative tendency of modernization education reform makes the English teaching mode of higher vocational colleges face up with the brand-new situation, but public English classroom of higher vocational colleges still can't solve lots of problems under the new situation in practice. The public English teaching mode of higher vocational colleges is still one of emphases in English teaching study of colleges. Under the background, the author firstly discussed and systemized the independent teaching theory. Then, beginning with the practice, the author specially analyzed the advantages and disadvantages of public English in higher vocational colleges. Under the precondition of finding out problems in these models, the author proposed a new mode by referring to the superiority of each teaching mode and promoted the superiority of higher vocational English education.

\section{The Teaching Mode Construction Method of Higher Vocational Public English Based on the Independent Study Theory}

\subsection{Investigation analysis on English independent study ability of higher vocational college students}

The researchers did a questionnaire on 100 students in 52 classes, 33 majors of our college, and granted 100 questionnaires, of which 94 questionnaires were recycled, including 91 effective questionnaires. The investigation results were shown as follows: 
Tab.1 The English Independent Study Ability Investigation on Higher Vocational College Students

\begin{tabular}{|c|c|c|}
\hline Items & Options & $\begin{array}{l}\text { Chosen } \\
\text { rate } \%\end{array}$ \\
\hline \multirow{3}{*}{$\begin{array}{l}\text { Your understanding on the } \\
\text { connotations of English } \\
\text { independent study in higher } \\
\text { vocational colleges }\end{array}$} & Have no idea & $46 \%$ \\
\hline & Understand & $26 \%$ \\
\hline & Know well & $28 \%$ \\
\hline \multirow{3}{*}{$\begin{array}{l}\text { Whether you are interested } \\
\text { in English independent study }\end{array}$} & Interested & $49 \%$ \\
\hline & General & $35 \%$ \\
\hline & Not interested & $16 \%$ \\
\hline \multirow{3}{*}{$\begin{array}{l}\text { Whether you have already } \\
\text { had the English independent } \\
\text { study ability(including the } \\
\text { independent study ability } \\
\text { under the guide of teachers } \\
\text { and completely independent } \\
\text { study ability) }\end{array}$} & Yes & $26 \%$ \\
\hline & Basically & $23 \%$ \\
\hline & No & $51 \%$ \\
\hline \multirow{3}{*}{$\begin{array}{l}\text { Do you think how can you } \\
\text { improve your English } \\
\text { independent study ability }\end{array}$} & $\begin{array}{l}\text { Depend on the teacher's assistance, guide, scientific and rational } \\
\text { management, supervision, inspection and evaluation measures }\end{array}$ & $56 \%$ \\
\hline & $\begin{array}{l}\text { Depend on the English independent study system under the } \\
\text { multi-media network environment }\end{array}$ & $30 \%$ \\
\hline & Depend on the textbooks & $14 \%$ \\
\hline \multirow{4}{*}{$\begin{array}{l}\text { What's the primary cause for } \\
\text { your poor English } \\
\text { independent study ability }\end{array}$} & Poor English foundation & $37 \%$ \\
\hline & No independent study consciousness, interest and motivation & $23 \%$ \\
\hline & $\begin{array}{l}\text { Insufficient teachers' management, guide and assistance, and } \\
\text { imperfect independent study effect detection and evaluation } \\
\text { mechanism }\end{array}$ & $19 \%$ \\
\hline & Limited network resources & $21 \%$ \\
\hline \multirow{3}{*}{$\begin{array}{l}\text { Do you hope to own the } \\
\text { English independent study } \\
\text { ability }\end{array}$} & Desire & $41 \%$ \\
\hline & Hope & $36 \%$ \\
\hline & Never mind & $23 \%$ \\
\hline \multirow{3}{*}{$\begin{array}{l}\text { The purpose of hoping to } \\
\text { own the English independent } \\
\text { study ability }\end{array}$} & Enhance the employment competitiveness & $67 \%$ \\
\hline & Lifelong study & $11 \%$ \\
\hline & Improve English integrated ability & $22 \%$ \\
\hline
\end{tabular}

\subsection{CDIO Teaching Idea}

The project group fully absorbs the CDIO teaching idea. CDIO refers to conception, design, implementation and operation. It is the new teaching mode that aims to realize independent study for students, active exploration and improvement of English application ability. This mode is based on the scene establishment. With the center of "study" and orientation of "problem driving", it emphasizes the ability to solve by hands and analyze problems, and learn how to gain effective information and abundant resources in English study website.

1) Promote listening by speaking and combination of listening and speaking: improvement of listening is closely linked with oral English. To value oral English is the primary task in the realization process. The listening and speaking class of the experimental class is grouped in line with the study group with the grouping principle of high, middle, and low levels. Each group has the same number. The groups discuss and exchange according to the teachers' topic. Moreover, students with different levels are designed with different levels of tasks. 2). Situation creation+ task driving: Teachers concept and carry out different situations of classroom activities in line with the different unit themes and require students to complete the given tasks in the established situations. 3) Students' practical teaching: Teachers arrange and design students' practical teaching process, such as assignment evaluation and test question explanation, apply "students' self-evaluation+ teachers' comments", and require students to focus on the "method+ idea". In this way, they can greatly grasp students' mastery and output knowledge and lay a foundation on the further education. In addition, students also establish the teaching process of British and American classical songs, such as the Big Big World, Yesterday Once More and My Love, and so on. Teachers can pick up student delegate 
to sing. In this way, this not only cultivates students' habits to independently study English songs in their spare time, but also activates the classroom atmosphere by teaching English songs.

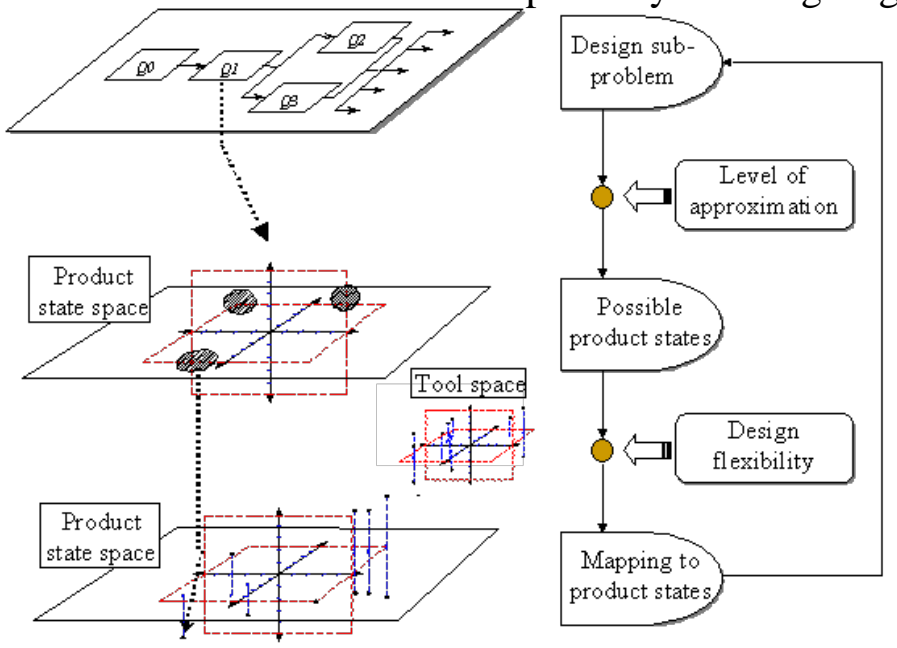

Fig.1 Design Process

\subsection{Significance of after-class assignment design}

Tab.2 Unit 1: The After-class Assignment Design

\begin{tabular}{|c|c|c|c|c|c|c|c|c|}
\hline \multirow[b]{2}{*}{ Teaching contents } & \multicolumn{8}{|c|}{ After-class assignment design } \\
\hline & Necessary contents & $\begin{array}{l}\text { Completion } \\
\text { method }\end{array}$ & Time & $\begin{array}{l}\text { Submission } \\
\text { mode }\end{array}$ & $\begin{array}{l}\text { Selective } \\
\text { contents }\end{array}$ & $\begin{array}{l}\text { Completion } \\
\text { method }\end{array}$ & Time & $\begin{array}{l}\text { Submission } \\
\text { mode }\end{array}$ \\
\hline $\begin{array}{l}\text { Words and Phrases } \\
\text { Practical English } \\
\text { Tutorial 1(Unit } 1 \\
\text { Education) }\end{array}$ & $\begin{array}{l}\text { Relevant word and } \\
\text { phrase exercise } \\
\text { questions in textbooks } \\
\text { and preview the } \\
\text { lesson }\end{array}$ & $\begin{array}{l}\text { Independent(in } \\
\text { dividual) }\end{array}$ & Next time & $\begin{array}{l}\text { Classroom } \\
\text { inspection }\end{array}$ & $\begin{array}{l}\text { Composition } \\
\text { exercise of } \\
\text { vocabulary }\end{array}$ & $\begin{array}{l}\text { Cooperation } \\
\text { (Group) }\end{array}$ & Next time & Written \\
\hline $\begin{array}{lr}\text { Text A and } & \text { Text B } \\
\text { Practical } & \text { English } \\
\text { Tutorial } & 1 \\
\text { (UINT1Education ) }\end{array}$ & $\begin{array}{l}\text { Relevant lesson } \\
\text { questions in the } \\
\text { textbook and translate } \\
\text { the text paragraph }\end{array}$ & $\begin{array}{l}\text { Independent(in } \\
\text { dividual) }\end{array}$ & Next time & $\begin{array}{l}\text { Classroom } \\
\text { inspection and } \\
\text { written }\end{array}$ & $\begin{array}{l}\text { Two } \\
\text { extracurricular } \\
\text { reading } \\
\text { materials } \\
\end{array}$ & $\begin{array}{l}\text { Independent } \\
\text { (individual) }\end{array}$ & $\begin{array}{l}\text { This } \\
\text { semester }\end{array}$ & Written \\
\hline $\begin{array}{lr}\text { Grammar } & \text { and } \\
\text { Writing } & \text { Practical } \\
\text { English Tutorial } 1 \\
\text { (UINT1Education ) }\end{array}$ & \begin{tabular}{l}
\multicolumn{1}{c}{ Composition } \\
exercise of \\
self-introduction/wor \\
kbook unit
\end{tabular} & $\begin{array}{l}\text { Independent(in } \\
\text { dividual) }\end{array}$ & $\begin{array}{l}\text { Next } \\
\text { time/this } \\
\text { semester }\end{array}$ & $\begin{array}{l}\text { Written } \\
\text { workbook }\end{array}$ & $\begin{array}{l}\text { PPT production } \\
\text { in line with the } \\
\text { assigned text }\end{array}$ & $\begin{array}{l}\text { Cooperation } \\
\text { (group) and } \\
\text { teachers' } \\
\text { guide }\end{array}$ & Next time & Network \\
\hline $\begin{array}{l}\text { Viewing, } \\
\text { Speaking } \\
\text { Listening }\end{array}$ & $\begin{array}{lr}\text { Listening } & \text { exercise } \\
\text { and } & \text { situation } \\
\text { conversation } & \text { of } \\
\text { Practical } & \text { English } \\
\text { Tutorial Unit } 1 & \end{array}$ & $\begin{array}{l}\text { Independent(in } \\
\text { dividual) and } \\
\text { cooperation }\end{array}$ & Next time & $\begin{array}{l}\text { Classroom } \\
\text { inspection and } \\
\text { oral expression }\end{array}$ & $\begin{array}{l}\text { Situation } \\
\text { conversation } \\
\text { exercise in line } \\
\text { with the } \\
\text { Modern Career } \\
\text { English } \\
\text { Textbook Unit } \\
1\end{array}$ & Cooperation & $\begin{array}{l}\text { This } \\
\text { semester }\end{array}$ & $\begin{array}{l}\text { Oral } \\
\text { expression }\end{array}$ \\
\hline
\end{tabular}

\section{The Empirical Study on the Higher Vocational English Public Teaching Mode Based on the Independent Study Theory}

In the first week and the end of semester (the $18^{\text {th }}$ week), English competence of students in the experimental class and control class are conducted the integrated testing. The performance results are shown in Table 3 and Table 4.

Tab. 3 The First Week Performance Statistics(Pre-testing)

\begin{tabular}{|l|c|c|c|c|c|c|}
\hline & $\begin{array}{c}\text { Listening } \\
20 \%\end{array}$ & $\begin{array}{c}\text { Vocabulary } \\
15 \%\end{array}$ & $\begin{array}{c}\text { Reading } \\
30 \%\end{array}$ & $\begin{array}{c}\text { Translation } \\
15 \%\end{array}$ & $\begin{array}{c}\text { Oral English } \\
20 \%\end{array}$ & Total \\
\hline $\begin{array}{l}\text { Experimental } \\
\text { class }\end{array}$ & 13.41 & 9.68 & 19.72 & 8.95 & 11.15 & 62.91 \\
\hline Control class & 12.79 & 10.02 & 20.07 & 7.82 & 12.33 & 63.03 \\
\hline
\end{tabular}


Tab. 4 The 19th Week Performance Statistics(Post-testing)

\begin{tabular}{|l|c|c|c|c|c|c|}
\hline & $\begin{array}{c}\text { Listening } \\
20 \%\end{array}$ & $\begin{array}{c}\text { Vocabulary } \\
15 \%\end{array}$ & $\begin{array}{c}\text { Reading } \\
30 \%\end{array}$ & $\begin{array}{c}\text { Translation } \\
15 \%\end{array}$ & $\begin{array}{c}\text { Oral English } \\
20 \%\end{array}$ & Total \\
\hline $\begin{array}{l}\text { Experimental } \\
\text { class }\end{array}$ & 16.01 & 10.11 & 22.36 & 9.31 & 17.13 & 74.92 \\
\hline Control class & 12.98 & 10.56 & 19.73 & 9.26 & 13.18 & 65.71 \\
\hline
\end{tabular}

From the perspective of Table 3 and Table 4, the overall performance and subitem performance of two classes before testing don't have the large difference. After testing, the overall performance of the experimental class is obviously better than the control class, especially for the listening and oral English performance, which can be verified in the classroom observation. Moreover, students in the experimental class are more confident in the classroom performance and they are willing to perform themselves and frequently exchange with students and teachers. The language output effect is also better. SPSS19 is used for statistical analysis, shown in Table 4-Table 8.

Tab.5 Performance before Teaching Experiment Test

\begin{tabular}{|c|c|c|c|c|}
\hline & Number & Mean value & Standard deviation & Standard error \\
\hline $\begin{array}{c}\text { Experimental } \\
\text { class }\end{array}$ & 64 & 62.9106 & 5.2923 & 0.5591 \\
\hline Control class & 64 & 63.0323 & 6.7275 & 0.9836 \\
\hline
\end{tabular}

Tab. 6 Independent Sample Test before Teaching Experiment

\begin{tabular}{|c|c|c|c|c|c|}
\hline & \multicolumn{2}{|c|}{$\begin{array}{c}\text { Levene test of variance } \\
\text { equation }\end{array}$} & \multicolumn{3}{|c|}{ t test of mean equation } \\
\hline & $\mathrm{F}$ & Sig. & $\mathrm{t}$ & $\mathrm{df}$ & Sig( 双侧) \\
\hline $\begin{array}{c}\text { Assuming that } \\
\text { variance is equal }\end{array}$ & 1.127 & 0.295 & 1.875 & 126 & 0.749 \\
\hline $\begin{array}{c}\text { Assuming that } \\
\text { variance is unequal }\end{array}$ & & & 1.875 & 124.332 & 0.749 \\
\hline
\end{tabular}

From the perspective of Table 7, performance in two classes before experiment is relatively close. The performance of students in the control class is slightly better than the performance of students in the experimental class. Based on Table $8, \operatorname{Sig}$ (double sides) $\mathrm{P}=0.749>0.05$, indicating that there is no significant difference in English level before testing between the experimental class and control class.

Tab. 7 Performance after the Teaching Test

\begin{tabular}{|c|c|c|c|c|}
\hline & Number & Mean value & Standard deviation & Standard error \\
\hline $\begin{array}{c}\text { Experimental } \\
\text { class }\end{array}$ & 64 & 74.9243 & 8.4470 & 1.0483 \\
\hline Control class & 64 & 65.7112 & 9.6573 & 1.2351 \\
\hline
\end{tabular}

Tab. 8 Independent Sampling Test after the Teaching Test

\begin{tabular}{|c|c|c|c|c|c|}
\hline & \multicolumn{2}{|c|}{$\begin{array}{c}\text { Levene test of variance } \\
\text { equation }\end{array}$} & \multicolumn{3}{c|}{ t test of mean equation } \\
\hline & $\mathrm{F}$ & $\mathrm{Sig}$ & $\mathrm{t}$ & $\mathrm{df}$ & $\mathrm{Sig}($ 双侧 $)$ \\
\hline $\begin{array}{c}\text { Assuming that } \\
\text { variance is equal }\end{array}$ & 1.401 & 0.229 & 4.235 & 126 & 0.000 \\
\hline $\begin{array}{c}\text { Assuming that } \\
\text { variance is unequal }\end{array}$ & & & 4.235 & 124.224 & 0.000 \\
\hline
\end{tabular}

It can be observed from Table 6 that the mean difference in two classes after testing is larger. The mean difference is 9.21, indicating that after studying one semester for students in the 
experimental class and control class, the performance in the experimental class is better than the control class, while Sig(double sides) in Table 8 , namely $\mathrm{P}=0.000<0.05$, showing that after teaching testing, the performance of the experimental class and control class can reach the statistical difference, indicating that the public English teaching mode based on the independent study theory contributes to improving English teaching effects and students’ English competence.

\section{The Learning Effect Evaluation System Analysis of College Students under the Big Data Environment}

High vocational English education pays more attention to improving students' English competence and focus on students' English competence cultivation on the basis of the general study ability for students. This requires the higher vocational English to break through the traditional cramming teaching mode, but embodies the flexible and independent educational idea and greatly meets the teaching tasks of higher vocational English in the current stage, and English study requirements of higher vocational respondents. The modern independent study idea is proposed on the basis of fully focusing on and respecting respondents' self-consciousness and decision. It emphasizes respondents' arrangement for learning targets, learning contents and learning process in the educational process and their control ability and support ability for independent study, self-evaluation and reflection on learning process. The subjects of realizing the independent study are students. In the traditional English teaching mode, teachers realize the final teaching targets through students. The tools for teachers to implement teaching planning and complete the teaching tasks are students. Under such a mode, it is hard for students to effectively master English knowledge or improve their English competence. Such a cramming English teaching mode can't be tested by practice. As a result, the real classroom subjects are not students. Students' learning behavior is passive. No matter for the teaching level, it is difficult to improve students' English competence.

\section{References}

[1] Huang Wenxing and Tang Wei, the Exploration and Practice of the Three-dimensional Teaching Mode in Higher Vocational Public English[J], Chinese Education Informatization, 2016(23): 42-45;

[2] Mu Lili, the Construction of the Higher Vocational English O2O Teaching Framework Based on Mooc[J], Henan Agriculture, 2017(03): 28-29;

[3] Gong Wenfang, the Higher Vocational Public English Digital Resource Bank Construction Based on the Relevance[J], Exploration of the Higher Vocational Education, 2017, 16(05): 76-80;

[4] Liu Yamei, the Exploration on the Flipped Class Model of Higher Vocational Public English Based on the Micro-class[J], Overseas English, 2017(24): 32-33;

[5] Dong Dongmou, the Discussion on the Higher Vocational English O2O Teaching Mode under the MOOC Environment[J], Henan Agriculture, 2016(36): 28-29 